\title{
Technology management practices among electric cooperatives in CARAGA
}

Dumaguit, James M.

College of Technology, Surigao State College of Technology, Surigao City, Philippines (jmd.ssct@gmail.com) Sal, Jerlou B.

College of Technology, Surigao State College of Technology, Surigao City, Philippines (jsal@ssct.edu.ph)

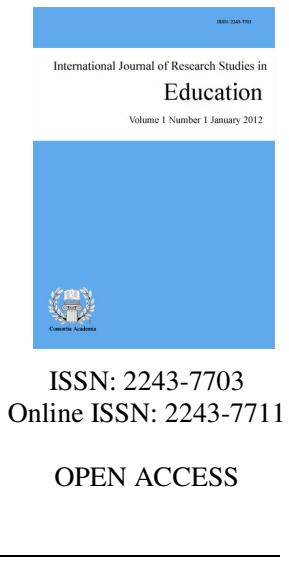

Received: 30 March 2021

\section{Abstract}

The objective of this study is to evaluate the technology management practices among electric cooperatives. It also discusses the basic management functions of planning, organizing, directing, controlling, and evaluating practices among the electric cooperatives. The descriptive method was used in this study. This design was deemed more appropriate because this study described the technology management practices in Electric Cooperatives in Caraga. The respondents of the study are the identified rank in file workers of the 6 Electric Cooperatives with a total population of 445 . This study used the mean and ordinal rank statistical tools in analysing the data. The data revealed that the technology management practices are much observed on factors of "Planning", the highest got the mean of 3.71 "Evaluating", second in rank with 3.60 mean, "Controlling" with mean of 3.59 and "Directing" with the mean of 3.55. However, the lowest is "Organizing" which got the mean of 3.56 and describe as much observed. The results implied that the employees observed much on the practices in the cooperatives that encourage them to perform their job and are encouraged to sustain their loyalty to their work for them to be able to provide basic services to their clientele. Likewise, the management is encouraged to sustain their best technology management practices and continue to integrate best practices of other organizations into their system to promote more satisfying and more effective service and quality production.

Keywords: technology management, electric cooperatives, practices, perceptions 


\section{Technology management practices among electric cooperatives in CARAGA}

\section{Introduction}

Technology management (TM) in general for companies is about sustaining and improving a company's competitiveness in the long term. This is all creating synergy among all the workers from low-ranking to top management to make them work together in the most efficient way to produce profit for the company in the long-term. In Caraga Region, there are several companies whose management functions of the executive officer and middle-level managers vary in carrying out their functions. With the different approaches, skills, and practices displayed and employed by managers with under constant pressure to be innovative, to introduce new products and services to create a difference in the market, and to make process innovations to improve their business performance and the way the managers have managed them are sometimes the reasons why workers have to feel either satisfaction or dissatisfaction. Technology Management involves the management of all the key factors of production to create wealth. The goal of technology management is to make everything work together in the most efficient way to produce profit for the company in the long term.

Electric Cooperatives in the Caraga region are soaring to have the latest innovation in technology. This action is a primary step to elevate its advancement using new technologies to fast track its work and projects and can serve better on its area coverage. With these strategic plans, electric cooperatives are developing new ways and techniques, adopting massive change that enables them to keep up the pace in technological advancement. Acquiring equipment, upgrading each system, and enhancing the individual skill of each worker is so vital that every cooperative must address it to ensure sustainability in the long run. In this premise, the researcher wanted to determine how the Electric Cooperative companies in Caraga Region are being managed and how their management practice affect the worker's satisfaction, hence this study.

\section{Review of literature}

Technology Management. Is a set of management disciplines that allows organizations to manage their technological fundamentals to create a competitive advantage. The role of the technology management function in an organization is to understand the value of certain technology for the organization. Continuous development of technology is valuable as long as there is value for the customer and therefore the technology management function in an organization should be able to argue when to invest in technology development and when to withdraw (Rusanen, 2009). Electric cooperatives adopt technology management that relates to innovation management with the perspective on how to acquire knowledge and transfer technologies into innovative products. In addition, most electric cooperatives able to embed these changes into their system by obtaining technological advancement suitable for their needs that can help them in broadening their projects and to ensure the quality of work.

Planning. The basic of all management functions which deals with sketching out a future course of action and deciding in advance the most appropriate course of action for the achievement of predetermined goals are planning (Koontz, 2012). He added that the role of planning in any organization is to anticipate how the company will go about achieving its goals and objectives. It is important to put a coherent system in place before launching into the action stage. Planning also involves decisions about the ways and means that will be brought to bear, i.e. both the choice of action plans to be set in motion and the identification and mobilization of the resources that are deemed necessary like financial, human, and material resources (Mikulok, 2013). But, inversely, risk levels will also be higher due to greater uncertainty.

The function of planning especially in Electric Cooperatives is found necessary for it determines the company's long-term objectives, finding a compromise between these two considerations (anticipation/risk). 
Strategic plans are generally formulated on a five-year time frame, but in reality, this greatly depends on the sector that the company operates in, as well as the magnitude of the action plans being considered (Carpenter, 2012). The planning aspect of management practices is a major contributor to the success and productivity of any business or industrial organization like the Electric Cooperatives. Stated simply, if a person does not know where he is going, then he will never know when and where he has arrived. Planning is the process of determining the company's goals and objectives and making provisions for their achievement. It involves choosing a course of action from available alternatives (Gollete, 2013).

Organizing. Organizing is the process of identifying and grouping the works to be performed, defining and delegating responsibility and authority, and establishing relationships to enable people to work most efficiently. Allen (2012), mentioned the process of organizing the organization. These are Division of work: The first process of organizing includes identification and division of work which shall be done by following the plans that are determined previously; Departmentation: once the work of identifying and dividing has been done those are similar are to be grouped; Linking departments: When the process of departmentation was completed, linking of departments has to be done so that those departments operate in a coordinated manner which gives a shape to overall organization structure, Assigning duties: On completion of departmentation process assigning duties i.e. defining authority and responsibility to the employees based on their skills and capabilities has to be done, which in consequence magnifies efficiency about concerning their work.

In any organizing effort, managers choose an appropriate structure. Organizational structure is represented primarily by an organizational chart. It specifies who will do it, what is to be done, and how it will be accomplished. The organizing stage provides directions for achieving the planning results. There are several aspects to organizing time, structures, a chain of command, degree of centralization, and role specification (Wadron, 2011). Proper organizing in the company is evident when workers develop self-confidence and satisfaction with their job. Hence, proper allocation of human resources and assigning works based on the extent of their abilities or qualification would be well-observed in this function (Llasos, 2011).

Directing. Directing is concerned with instructing, guiding, supervising, and inspiring people in the organization to achieve its objectives (George \& Jerry, 2012). Furthermore, this emphasized that it is the process of telling people what to do and seeing that what they do is in the best possible manner and aligned with what is in the company goals. Putting the right person is a part of a directing function. If the person knows his work, the goals and objectives of the organization would have been realized immediately. Directing involves supervision, which is essential to make sure that work is performed according to the orders and instructions. Different people perform different activities in the organization. All the activities are interrelated. To coordinate the activities carried out in different parts and to ensure that they are performed well, directing is important. Thus, it helps to integrate the various activities and so also the individual goals with organizational goals. Directing involves leadership that essentially helps in creating an appropriate work environment and build up team spirit.

Controlling. Controlling is one of the managerial functions like planning, organizing, staffing, and directing. It is mainly concerned with the measurement and correction of organizational performance. This is an important function because it helps to check the errors and to take corrective action so that deviation from standards are minimized and stated goals of the organization are achieved in the desired manner (Fareed, 2014). In the electrical world, electrical-related problems are prevented when controlling managerial function is strictly observed and implemented. According to modern concepts, control is a foreseeing action whereas the earlier concept of control was used only when errors were detected. Control in management means setting standards, measuring actual performance, and taking corrective action.

Controlling in an electric cooperative consists of verifying whether everything occurs in conformities with the plans adopted, instructions issued and principles established. Controlling ensures that there is effective and efficient utilization of organizational resources to achieve the planned goals. Controlling measures the deviation of actual performance from the standard performance, discovers the causes of such deviations, and helps in 
taking corrective and preventive actions. Also, controlling is a systematic exercise which is called a process of checking actual performance against the standards or plans to ensure adequate progress and also recording such experience as is gained as a contribution to possible future needs. Donnell (2009) stressed that just as a navigator continually takes reading to ensure whether he is relative to a planned action, so should a business manager continually take reading to assure himself that his enterprise is on the right course.

Evaluation. It is a systematic determination of a subject's merit, worth and significance, using criteria governed by a set of standards. It can assist an organization, program, project, or any other intervention or initiative to assess any aim, realizable concept/proposal, or any alternative, to help in decision-making; or to ascertain the degree of achievement or value regarding the aim and objectives and results of any such action that has been completed. The primary purpose of evaluation, in addition to gaining insight into prior or existing initiatives, is to enable reflection and assist in the identification of future change. Evaluation is the structured interpretation and giving of meaning to predict or actual impacts of proposals or results. It looks at original objectives, and at what is either predicted or what was accomplished and how it was accomplished. Shuffle (2010) stressed that evaluation can be formative that is taking place during the development of a concept or proposal, project or organization, to improve the value or effectiveness of the proposal, project, or organization.

In companies particularly in Electric Cooperatives, talking evaluation as a function is a crucial process. This implies that evaluation indicates a big role with a high level of standard. It measures the whole process on how it is being implemented and it monitors in detail how the system goes. In this manner of the management process, evaluation is the most effective strategy in finding out a solution by discovering things that are not working properly, its project status, upgrading equipment, and enhancing systems in dealing with clients, and most of all through evaluation it improves workers' skills and capabilities. It is in this aspect of the management process, where evaluation can watch over the company's setbacks and be able to correct them so that they will enrich the company's improvement in the long run.

\subsection{Objectives of the study}

The general objective of this study is to evaluate the technology management practices among electric cooperatives in CARAGA Region.

\subsection{Framework of the study}

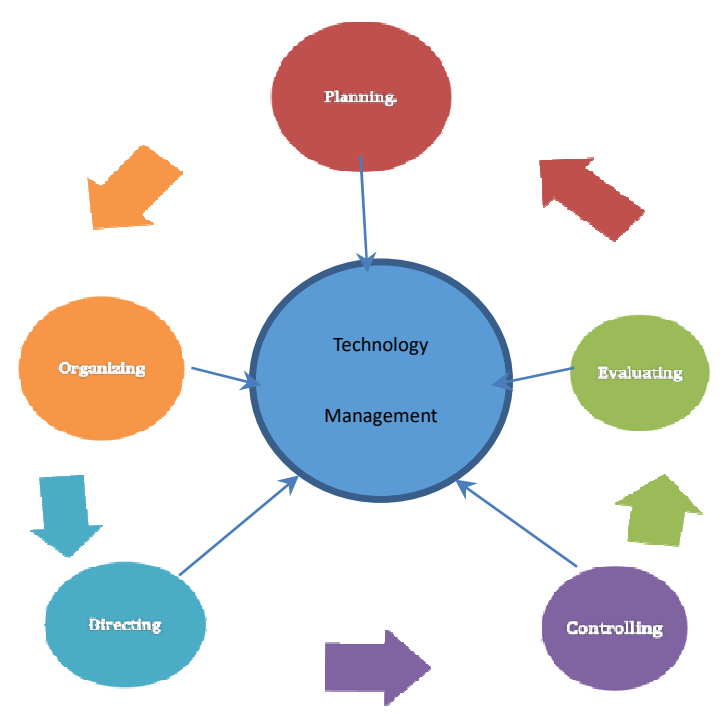

Figure 1. Theoretical Framework 


\section{Research methodology}

\subsection{Research design}

A descriptive method was used in this study. This design was deemed more appropriate because this study described the technology management practices in Electric Cooperatives, Caraga Administrative region.

\subsection{Research environment}

The present study was conducted in Caraga Administrative Region. Figure 3 shows the Map of Caraga Region where the study will be undertaken. The Caraga Region was created through Republic Act Number 7901 on February 25, 1995. The region is composed of five (5) provinces: Agusan del Norte, Agusan del Sur, Dinagat Island, Surigao del Norte and Surigao del Sur; six (6) cities: Butuan, Cabadbaran, Bayugan, Surigao,Tandag and Bislig; sixty-seven (67) municipalities and 1,308 barangays. Butuan City is the regional center.

\subsection{Respondents}

The respondents of the study are the identified rank in file workers of the Electric Cooperatives, Inc, Caraga Administrative Region. The sample size was determined by at least $50 \%+1$ of the population but more sample size yields better approximation of the population; thus the researcher managed to take as many as 283 samples. Table 1 presents the population and sample of the respondents in the study ranked in file workers of six (6) Electric Cooperatives Inc. of Caraga Administrative Region.

\section{Table 1}

Distribution of the respondents

\begin{tabular}{lccc}
\hline \multicolumn{1}{c}{ Cooperative } & $\mathrm{N}$ & $\mathrm{n}$ & $\%$ \\
\hline ANECO & 200 & 128 & 64.00 \\
ASELCO & 60 & 38 & 63.33 \\
DIELCO & 30 & 19 & 63.33 \\
SIARELCO & 35 & 22 & 62.86 \\
SURNECO & 60 & 38 & 63.33 \\
SURSECO & 60 & 38 & 63.33 \\
Total & 445 & 283 & 63.60 \\
\hline
\end{tabular}

\subsection{Research instrument}

The instrument to be used in the study is the researcher- made questionnaire which was anchored on the previous related studies. The questionnaire contains pertinent questions to be checked and supplied answers by the respondents.

\subsection{Data analysis}

This study used the following statistical tools in analyzing the data.

Mean and Ordinal Rank. These were used to determine the technology management practices as to planning, organizing, directing, controlling, decision making, and evaluating

Weighted mean. This is used to analyze the data pertaining to the technology management practices in the cooperatives as assessed by the respondents.

Pearson $\mathbf{r}$ and t-test. These were employed to test the significant relationship among technology management practices in the cooperatives. 


\section{Results and Discussion}

\subsection{Technology management practices as to planning}

Table 2

Technology management practices as to planning

\begin{tabular}{|c|c|c|c|c|}
\hline Statements & Mean & Rank & VI & QD \\
\hline $\begin{array}{l}\text { 1. Sets the company's philosophy, vision, mission } \\
\text { and objectives. }\end{array}$ & 3.90 & 1 & $\mathrm{SA}$ & MO \\
\hline $\begin{array}{l}\text { 2. Formulates policies, rules and regulations of } \\
\text { the Electric Cooperative. }\end{array}$ & 3.82 & 2 & SA & MO \\
\hline 3. Plans ahead to complete assignments & 3.75 & 3 & SA & MO \\
\hline $\begin{array}{l}\text { 4. Develops strategies and procedures in promoting } \\
\text { work efficiency and productivity. }\end{array}$ & 3.74 & 4 & SA & MO \\
\hline $\begin{array}{l}\text { 5. Prepares calendar of activities for the whole } \\
\text { Fiscal Year. }\end{array}$ & 3.69 & 5 & SA & MO \\
\hline $\begin{array}{l}\text { 6. Allocates specific budget for all its project } \\
\text { works. }\end{array}$ & 3.68 & 6 & SA & MO \\
\hline 7. Prepares the annual procurement plan. & 3.67 & 7 & SA & MO \\
\hline 8. Observes time-frame plan for all project. & 3.61 & 10 & SA & MO \\
\hline 9. Initiates back-up plan during calamities. & 3.65 & 8 & SA & MO \\
\hline $\begin{array}{l}\text { 10.Sets plan in improving it physical facilities } \\
\text { and equipment }\end{array}$ & 3.63 & 9 & $\mathrm{SA}$ & MO \\
\hline Average Mean & 3.71 & & SA & MO \\
\hline
\end{tabular}

It can be seen that all items are interpreted as Strongly Agree and described as Much Observed that planning is practiced by the Electric Cooperatives as confirmed in its average mean of 3.71. Specifically, item 1 "Sets the

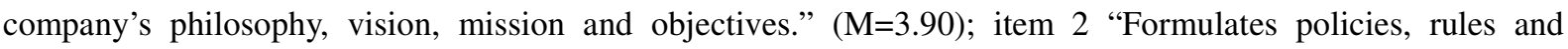
regulations of the Electric Cooperative." (M=3.82); item 3 "Plans ahead to complete assignments" $(\mathrm{M}=3.75)$, item 4 "Develops strategies and procedures in promoting work efficiency and productivity." and item 5 "Prepares calendar of activities for the whole Fiscal Year" $(M=3.69)$ are the statements which got the first five highest means with a qualitative description of Much Observed. This suggests that the Electric Cooperatives in Caraga Region have established its VMGO and how it is to be attained by employing doable strategies and relevant activities.

Hill (2013) recounted that planning helps an organization chart a course for the achievement of its goals. The process begins with reviewing the current operations of the organization and identifying what needs to be improved operationally in the upcoming year. From there, planning involves envisioning the results the organization wants to achieve, and determining the steps necessary to arrive at the intended destination--success, whether that is measured in financial terms, or goals that include being the highest-rated organization in customer satisfaction.

\subsection{Technology management practices as to organizing}

Organizing seen in Table 3 are the responses of the respondents on how observable are the technology management practices in Electric Cooperatives in terms of Organizing. It is evident that organizing is Much Observed as seen in its average mean of 3.56. This implies that whatever is undertaken in the office or even in the field by the workers is in accordance with their job definition and based on its citizen charter. Specifically, item 1 "Does an excellent job of keeping informed about matters affecting its employees." ranked first with the mean of 3.68 and described as Much Observed. Item 9 "Makes sure that the income every day is audited and accounted for." ranked second with a mean of 3.64, described as Much Observed. Item 7 "Sees to it that offices are strategically located." ranked third with a mean of 3.60, described as Much Observed. Item 8 "Makes sure that the

6 Consortia Academia Publishing (A partner of Network of Professional Researchers and Educators) 
Technology management practices among electric cooperatives in CARAGA

electrical equipment \& supplies are put in place" obtained the fourth rank with a mean of 3.58, described as Much Observed and the fifth item is “Observes citizen's charter." having the mean of 3.56, described as Much Observed

\section{Table 3}

Technology management practices as to organizing

\begin{tabular}{|c|c|c|c|c|}
\hline Statements & Mean & Rank & VI & QD \\
\hline $\begin{array}{l}\text { 1. Does an excellent job of keeping } \\
\text { informed about matters affecting its } \\
\text { employees. }\end{array}$ & 3.68 & 1 & SA & MO \\
\hline $\begin{array}{l}\text { 2. Defines and analyzes jobs of the } \\
\text { employees. }\end{array}$ & 3.54 & 7 & SA & MO \\
\hline 3. Observes citizen's charter. & 3.56 & 5 & SA & MO \\
\hline $\begin{array}{l}\text { 4. Circulates the information to } \\
\text { different department for wide } \\
\text { dissemination. }\end{array}$ & 3.55 & 6 & SA & MO \\
\hline $\begin{array}{l}\text { 5. Emphasizes decision-making on the } \\
\text { basis of democracy. }\end{array}$ & 3.49 & 9 & A & o \\
\hline $\begin{array}{l}\text { 6. Organizes each duty of work suitable } \\
\text { to every employee. }\end{array}$ & 3.52 & 8 & SA & MO \\
\hline $\begin{array}{l}\text { 7. Sees to it that offices are } \\
\text { strategically located. }\end{array}$ & 3.60 & 3 & SA & MO \\
\hline $\begin{array}{l}\text { 8. Makes sure that the electrical } \\
\text { equipment \& supplies are put in } \\
\text { place }\end{array}$ & 3.58 & 4 & SA & MO \\
\hline $\begin{array}{l}\text { 9. Makes sure that the income everyday } \\
\text { is audited and accounted. }\end{array}$ & 3.64 & 2 & SA & MO \\
\hline $\begin{array}{l}\text { 10. Sees to it that employees have } \\
\text { strictly observed time. }\end{array}$ & 3.46 & 10 & A & $\mathrm{O}$ \\
\hline Average Mean & 3.56 & & SA & MO \\
\hline
\end{tabular}

Venule (2013) expressed that in any organization, may it be small or big, organizing plays a vital role for its success because it is through organizing that the organizational structure is created. It is in this function on what tasks are to be done, which is to do them or how the tasks are to be made. Organizing is important to managers or even to the rank and file employees because it is in this function where specialization in one's' work is defined.

\subsection{Technology management practices as to directing}

Table 4

Technology management practices as to directing

\begin{tabular}{|c|c|c|c|c|}
\hline Statements & Mean & Rank & VI & QD \\
\hline $\begin{array}{l}\text { 1. Motivates employees to perform well in the } \\
\text { company. }\end{array}$ & 3.64 & 1 & $\mathrm{SA}$ & MO \\
\hline $\begin{array}{l}\text { 2. Direct employees to do their tasks as } \\
\text { stipulated in the citizen's charter }\end{array}$ & 3.54 & 9 & $\mathrm{SA}$ & $\mathrm{MO}$ \\
\hline $\begin{array}{l}\text { 3. Expects every employees regarding of their } \\
\text { job performance. }\end{array}$ & 3.58 & 5 & $\mathrm{SA}$ & $\mathrm{MO}$ \\
\hline $\begin{array}{l}\text { 4. Gives orders in line with the nature of my } \\
\text { job. }\end{array}$ & 3.55 & 8 & SA & $\mathrm{MO}$ \\
\hline $\begin{array}{l}\text { 5. Implements the policies, rules and } \\
\text { regulations. }\end{array}$ & 3.56 & 7 & SA & MO \\
\hline $\begin{array}{l}\text { 6. Executes coordinated and precise policies and } \\
\text { rules in responding to calamities. }\end{array}$ & 3.60 & 3 & $\mathrm{SA}$ & $\mathrm{MO}$ \\
\hline 7. Conducts in-service seminar. & 3.59 & 4 & SA & MO \\
\hline $\begin{array}{l}\text { 8. Sends the employees to seminar for } \\
\text { professional growth. }\end{array}$ & 3.62 & 2 & SA & $\mathrm{MO}$ \\
\hline $\begin{array}{l}\text { 9. Requires the employees to submit their } \\
\text { accomplishment reports. }\end{array}$ & 3.57 & 6 & SA & $\mathrm{MO}$ \\
\hline $\begin{array}{l}\text { 10. Requires the employees to submit their } \\
\text { individual plan of action. }\end{array}$ & 3.40 & 10 & A & $\mathrm{O}$ \\
\hline Average Mean & 3.57 & & SA & MO \\
\hline
\end{tabular}


Directing in Table 4 reveals the technology management practices of the Electric Cooperatives in Caraga Region in terms of directing function. Gleaned in the Table that the Electric Cooperative in general is operating with direction as evidenced in the average mean of 3.57, described as Much Observed.

It is further revealed that the company motivates employees to perform well in the company $(\mathrm{M}=3.64 ; \mathrm{QD}=$ Much Observed); sends the employees to seminar for professional growth ( $\mathrm{M}=3.62$; $\mathrm{QD}=$ Much Observed); executes coordinated and precise policies and rules in responding to calamities $(\mathrm{M}=3.60 ; \mathrm{QD}=\mathrm{Much}$ Observed); conducts in-service seminar $(\mathrm{M}=3.59 ; \mathrm{QD}=$ Much Observed) and expects every employees regarding of their job performance (M=3.59; QD=Much Observed).

Directing or Direction function is said to be the heart of management of process and therefore, is the central point around which accomplishment of goals take place. Whether VMGO has already been crafted and readily implemented, if the manager does not have the directing function, still the entire operation of the company would be useless. Direction is the function which is the starting point of the work performance of subordinates. It is from this function the action takes place, subordinates understand their jobs and do according to the instructions laid. Whatever plans are laid, can be implemented only once the actual work starts. It is there that direction becomes beneficial (Benetton, 2013).

\subsection{Technology management practices as to controlling}

\section{Table 5}

Technology management practices as to controlling

\begin{tabular}{|c|c|c|c|c|}
\hline Practice & Mean & Rank & VI & QD \\
\hline $\begin{array}{l}\text { 1. Sees to it that the quality of work conforms } \\
\text { to its standards. }\end{array}$ & 3.72 & 1 & SA & MO \\
\hline $\begin{array}{l}\text { 2. Provides adequate schedule for every } \\
\text { employees }\end{array}$ & 3.54 & 10 & SA & MO \\
\hline 3. Oversees the performance of the personnel. & 3.58 & 6 & SA & MO \\
\hline $\begin{array}{l}\text { 4. Ensures that all resources are properly } \\
\text { monitored and utilized. }\end{array}$ & 3.60 & 4 & SA & MO \\
\hline $\begin{array}{l}\text { 5. Exercises resources control and material } \\
\text { management. }\end{array}$ & 3.61 & 3 & SA & MO \\
\hline $\begin{array}{l}\text { 6. Allots appropriate supplies and materials } \\
\text { needed for the job. }\end{array}$ & 3.57 & 7 & SA & MO \\
\hline $\begin{array}{l}\text { 7. Spends funds based on the existing auditing } \\
\text { and accounting rules. }\end{array}$ & 3.56 & 8 & SA & MO \\
\hline $\begin{array}{l}\text { 8. Purchases materials based on annual } \\
\text { procurement plan. }\end{array}$ & 3.59 & 5 & SA & MO \\
\hline $\begin{array}{l}\text { 9. Distributes office supplies to different } \\
\text { departments as stipulated in the annual } \\
\text { procurement plan. }\end{array}$ & 3.55 & 9 & SA & $\mathrm{MO}$ \\
\hline $\begin{array}{l}\text { 10. Procures supplies and materials needed for } \\
\text { the current fiscal year. }\end{array}$ & 3.62 & 2 & SA & MO \\
\hline Average Mean & 3.59 & & $\mathrm{SA}$ & MO \\
\hline
\end{tabular}

Controlling as one of the technology management practices of the Electric Cooperatives is practised by them. The average mean of 3.59 entails that this managerial function of controlling is Much Observed in the Electric Cooperatives operating in Caraga Administrative Region. To be more specific, the company sees to it that the quality of work conforms to its standards (M=3.72, QD=Much Observed); procures supplies and materials needed for the current fiscal year $(\mathrm{M}=3.62, \mathrm{QD}=$ Much Observed); exercises resources control and material management $(\mathrm{M}=3.61$; $\mathrm{QD}=\mathrm{Much}$ Observed), ensures that all resources are properly monitored and utilized $(\mathrm{M}=3.60 ; \mathrm{QD}=$ Much Observed) and purchases materials based on annual procurement plan (M=3.59; QD=Much Observed). These indicate that the existing standards, rules and regulations in the Cooperative are strictly adhered by its employees and its performance are constantly monitored and evaluated for the purpose of workers' continual improvement.

8 Consortia Academia Publishing (A partner of Network of Professional Researchers and Educators) 
4.5 Technology management practices as to evaluating

Table 6

Technology management practices as to evaluating

\begin{tabular}{|c|c|c|c|c|}
\hline Practice & Mean & Rank & VI & QD \\
\hline $\begin{array}{l}\text { 1. Evaluates the work performance of the } \\
\text { employees on a regular basis. }\end{array}$ & 3.70 & 2 & SA & MO \\
\hline $\begin{array}{l}\text { 2. Monitors if the performance of the employees } \\
\text { is aligned to the VMGO of the company. }\end{array}$ & 3.64 & 4 & SA & MO \\
\hline $\begin{array}{l}\text { 3. Provides to the employees with actionable } \\
\text { suggestions on what they can do to improve. }\end{array}$ & 3.57 & 7 & SA & MO \\
\hline 4. Sets realistic performance expectations. & 3.54 & 9 & SA & MO \\
\hline $\begin{array}{l}\text { 5. Conducts one-on-one conference for the } \\
\text { purpose of performance feedbacking. }\end{array}$ & 3.35 & 10 & A & $\mathrm{O}$ \\
\hline 6. Evaluates the accomplishment of its project. & 3.60 & 6 & SA & MO \\
\hline 7. Examines thoroughly its financial report. & 3.73 & 1 & SA & MO \\
\hline 8. Checks the DTR's of the employees. & 3.60 & 5 & SA & MO \\
\hline $\begin{array}{l}\text { 9. Inspects the physical plant and facilities of } \\
\text { the building }\end{array}$ & 3.56 & 8 & SA & MO \\
\hline $\begin{array}{l}\text { 10. Observes preventive maintenance on the } \\
\text { electrical power lines and posts on regular } \\
\text { basis. }\end{array}$ & 3.66 & 3 & SA & MO \\
\hline Average Mean & 3.60 & & SA & $\mathrm{MO}$ \\
\hline
\end{tabular}

Table 6 reflects the evaluating function as one of the technology management practices of the Electric Cooperative in Caraga Region. It can be seen that this function is Much Observed as confirmed in its average mean of 3.60. The details of this function is shown through its constant examination of its financial report ( $M=3.73$; QD=Much Observed), evaluation of the work performance of the employees on a regular basis ( $M=3.70$; $\mathrm{QD}=$ Much Observed), observation of preventive maintenance on the electrical power lines and posts on regular basis(M=3.66; $\mathrm{QD}=$ Much Observed), monitoring if the performance of the employees is aligned to the VMGO of the company ( $M=3.64$; QD=Much Observed)and checking of the DTR's of the employees (M=3.60; $\mathrm{QD}=$ Much Observed). These suggest that the Electric Cooperatives make sure that their work operations are directed towards the realization of its Objectives and are monitored and evaluated regularly as to whether it conforms to its standards and culture.

Patton (2009) elucidated the significance of evaluation of performance among the employees in the organization. He stressed that it is important to periodically assess and adapt the activities to ensure they are as effective as they can be. Evaluation can help everyone identify areas for improvement and ultimately help the organization realize its goals more efficiently. Additionally, when the results are being feedback to the concerned individual about what was more and less effective, it would help advance and improve the employees' performance. Moreover, evaluation enables an organization to demonstrate its success or progress. The information to be collected from evaluation allows the organization to better communicate its performance impact to others, which is critical for public relations, staff morale, and attracting and retaining support from current and potential funders.

\section{Recommendations}

Based on findings of the study, the following recommendations are offered:

1. Electric Cooperatives. They are encouraged to sustain their best technology management practices and continue to integrate best practices of other organizations to their system to promote more satisfying and more effective service and quality production. 
2. General Managers. They are motivated to reorganize their system and include technology management aspects to create a synergy among the workers to make them work together in the most efficient way in order to sustain and improve company's competitiveness and produce profit for the company in the long-term.

3. Employees. They are encouraged to sustain their loyalty to their work for them to be able to provide basic services to their clientele with a light and happy heart and through their quality service; their clientele would experience satisfaction which in turn provide them too with personal satisfaction as an employee.

4. Consumers. These are encouraged to give feedback to the kind of services being provided to them by the workers in the Electric Cooperative for the purpose of continuous improvement of their products and services.

5. Researchers. They are encouraged to replicate the present study by broadening its scope and variables and use the findings as additional input or references when a similar study is replicated.

\section{References}

Benetton, M. (2013). Importance of directing function. Retrieved from http://managementstudyguide.com

Bewley, I. (2010). Importance of harmonious relationship. Retrieved from http://www.humanrelationsstudyguide.com.htm

Bhatawdekar, S. (2012). Retrieved from http://functions-of-management.blogspot.com/

Carpenter, M., Bauer, T., \& Erdogan, B. (2012). Principles of management. Retrieved from https://flatworldknowledge.com

Fareed, S. (2014). Controlling: An important function of management. Retrieved from http://expertscolumn.com George, \& Jerry. (2012). Management functions. Retrieved from http://www.managementstudyguide.com/management_functions.html

Gollete, F. (2013). Planning for the company. Retrieved from http://planning.com

Hill, B. (2013). The importance of planning in the organization. Retrieved from http://smallbusiness.chron.com/importance-planning-organization-1137.html

Koontz, H. (2012). Planning in business management. Retrieved from http://www.ask.com

Letchken, O. (2014). Employee relations - Importance and ways of improving employee relations. Retrieved from http://www.managementstudyguide.com

Mikulok, K. (2013). Planning in management: Strategic, tactical, and operational plans. Retrieved from https://www.udemy.com

Petryni, O. (2013). Organizations. New York: Wiley.

Pujari, S. (2014). What is the importance of controlling? Retrieved from http://www.yourarticlelibrary.com/

Schultz, S. E. (2010). Psychology and work today: An introduction to industrial and organizational psychology

(10th ed.). New York City: Prentice Hall.

Wadron, S. (2011). Improving the managerial functions. Guelph. 